\title{
Tc-99m sestamibi scintigraphy and primary hyperparathyroidism: uptake beyond parathyroid glands
}

\author{
Daniela Dias, ${ }^{1}$ Joana Simões-Pereira, ${ }^{1}$ Valeriano Leite ${ }^{1,2}$
}

${ }^{1}$ Endocrinology Department, Instituto Portugues de Oncologia de Lisboa, Francisco Gentil, Lisbon, Portugal ${ }^{2}$ Nova Medical School/ Faculdade de Ciências Médicas, Universidade Nova de Lisboa, Lisbon, Portugal

Correspondence to

Dr Daniela Dias,

daniela_dias10@hotmail.com

Accepted 6 April 2018
Check for updates

To cite: Dias $D$

Simões-Pereira J, Leite V. BMJ Case Rep Published Online First: [please include Day Month Year]. doi:10.1136/ bcr-2018-225232

\section{DESCRIPTION}

Brown tumours (BTs) are one of the complications of long-standing hyperparathyroidism, being rare in developed countries. Tc-99m sestamibi scintigraphy (MIBI) is currently the gold standard for eutopic/ ectopic parathyroid tissue localisation in primary hyperparathyroidism $(\mathrm{PH})$. There are only a few reports showing BT uptake in whole-body MIBI. ${ }^{1-3}$
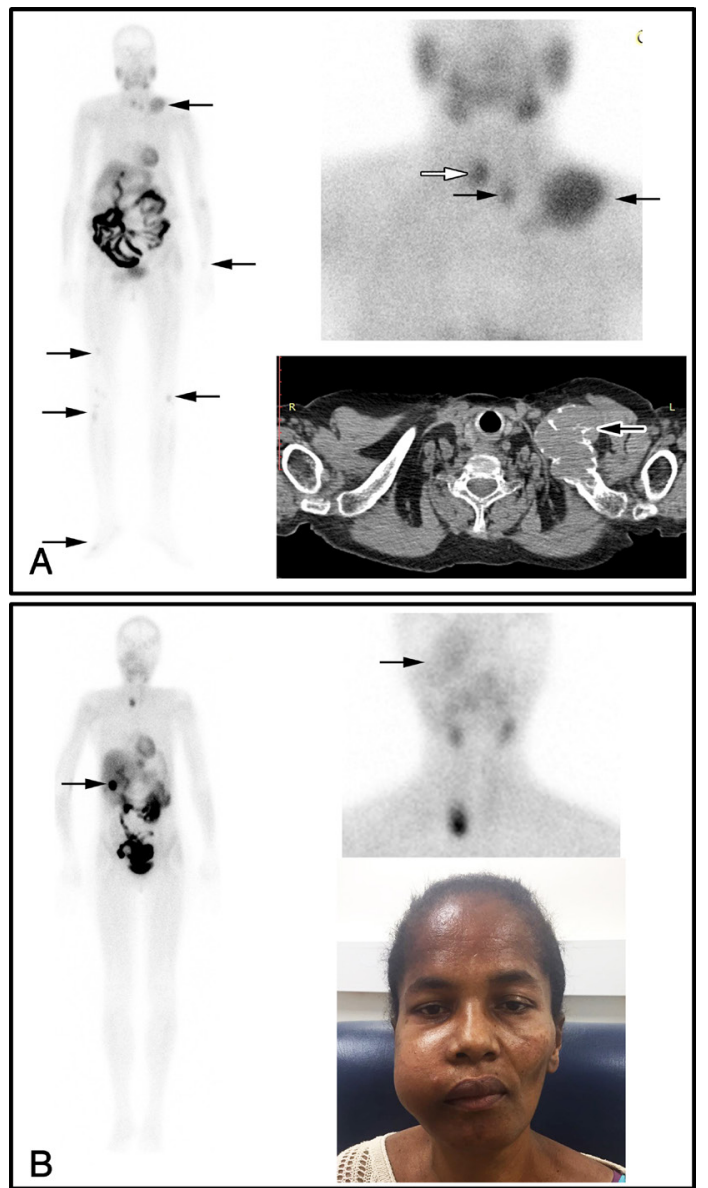

Figure 1 Panel A corresponds to patient 1 and shows a neck-chest CT scan revealing a brown tumour of the left clavicle and a whole-body view of MIBI scan showing uptake in the inferior left pole of the thyroid, in the right thyroid lobe and in multiple bone lesions. Panel B corresponds to patient 2 and depicts a whole-body MIBI with uptake in the inferior pole of the right thyroid lobe, right maxilla, ribs and epigastric area (arrows). Swelling on the right side of the zygomatic bone is evident on the photo of the patient. MIBI, Tc-99m sestamibi scintigraphy.
The first case is a 72-year-old caucasian woman, with a history of right nephrectomy for renal lithiasis at the age of 49 and a left clavicle fracture at the age of 70 , who presented with an enlarging mass in the fracture site $(\sim 6 \mathrm{~cm})$. Laboratory data showed an elevated serum level of calcium (sCa) of $12.8 \mathrm{mg} / \mathrm{dL}$ [normal range (NR): 8.4-10.2], alkaline phosphatase (ALP) of $264 \mathrm{UI} / \mathrm{L}$ (NR: 9-36) and parathyroid hormone $(\mathrm{PTH})$ of $1056 \mathrm{pg} / \mathrm{mL}$ (NR: 12-65), and decreased serum phosphorus (sPi) of $2.1 \mathrm{mg} / \mathrm{dL}$ (NR: $2.3-4.7$ ) with $25-\mathrm{OH}$ vitamin D of $33 \mathrm{ng} / \mathrm{mL}$ (NR 9-45), consistent with $\mathrm{PH}$. MIBI showed uptake in the inferior pole of the left thyroid lobe, in the right thyroid lobe and in multiple bone lesions (figure 1A). A neck and chest CT scan revealed multiple lytic lesions of the skeleton, including the left clavicle (figure 1A), and a pathological right mandibular fracture. The patient underwent a left inferior parathyroidectomy and total thyroidectomy.

The second case is a 50-year-old black woman, without remarkable medical history, who presented with an enlarging right zygomatic mass in the last 6 months (figure 1B). Blood tests revealed an elevated sCa of $16.5 \mathrm{mg} /$ $\mathrm{dL}$, ALP of $593 \mathrm{UI} / \mathrm{L}$ and PTH of $1204 \mathrm{pg} / \mathrm{mL}$, and decreased sPi $1.9 \mathrm{mg} / \mathrm{dL}$ and normal $25-\mathrm{OH}$ vitamin D $(33 \mathrm{ng} / \mathrm{mL})$. MIBI showed uptake in the inferior pole of the right thyroid lobe, right maxilla and epigastric area (figure 1B). This latter uptake was interpreted as a haemangioma on the abdominal ultrasound (US) and CT scan. Neck US demonstrated a $36 \mathrm{~mm}$ cystic nodule inferior to the right lobe and a $26 \mathrm{~mm}$ spongiform nodule on the right lobe. A right hemithyroidectomy and a right inferior parathyroidectomy were performed. Genetic analysis in this patient revealed a heterozygous pathogenic germline mutation, c. 306G $>$ A in exon 3 of the HRPT2 gene.

These two patients developed hungry bone syndrome immediately after surgery. Histology revealed parathyroid adenomas in both cases $(25 \times 15 \times 6 \mathrm{~mm}$ in patient 1 and $32 \times 26 \times 20 \mathrm{~mm}$ in patient 2), a right lobe papillary thyroid carcinoma in the first patient and nodular hyperplasia in the second patient. A decrease in the size of BTs was later noticed in both patients.

The presence of extraparathyroid lesions on MIBI scan may lead to diagnostic pitfalls, as shown in these two cases. In patient 1 , MIBI uptake was present in BTs and in a thyroid nodule, which persisted after washout, suggesting thyroid 


\section{Learning points}

Brown tumours are an uncommon manifestation of primary hyperparathyroidism.

- The presence of extraparathyroid lesions in Tc-99m sestamibi scintigraphy may lead to diagnostic pitfalls.

- In a patient with a long-standing hyperparathyroidism, the uptake of brown tumours in Tc-99m sestamibi scintigraphy can mimic a parathyroid carcinoma with bone metastasis.

malignancy; in patient 2, a liver haemangioma was revealed by the MIBI scan. In both cases, markedly increased PTH levels, together with MIBI uptake in multiple bones, required differential diagnosis with a parathyroid carcinoma with bone metastases. The benign nature of the bone lesions with MIBI uptake was demonstrated by its decrease in size following surgery. The underlying mechanisms for the increased uptake of MIBI in BT are not fully understood and may be related to increased local inflammation/vascularisation. ${ }^{3}$
Contributors The present article refers to two clinical cases followed and managed through medical consultation on a regular basis by DD and JS-P. DD, JS-P and VL wrote the manuscript and approved it for publication.

Funding The authors have not declared a specific grant for this research from any funding agency in the public, commercial or not-for-profit sectors.

Competing interests None declared.

Patient consent Obtained.

Provenance and peer review Not commissioned; externally peer reviewed.

(c) BMJ Publishing Group Ltd (unless otherwise stated in the text of the article) 2018. All rights reserved. No commercial use is permitted unless otherwise expressly granted.

\section{REFERENCES}

1 Khalil PN, Heining SM, Huss R, et al. Natural history and surgical treatment of brown tumor lesions at various sites in refractory primary hyperparathyroidism. Eur J Med Res 2007;12:222-30.

2 Rubin MR, Livolsi VA, Bandeira F, et al. Tc99m-sestamibi uptake in osteitis fibrosa cystica simulating metastatic bone disease. J Clin Endocrinol Metab 2001;86:5138-41.

3 Meng Z, Zhu M, He Q, et al. Clinical implications of brown tumor uptake in wholebody 99mTc-sestamibi scans for primary hyperparathyroidism. Nucl Med Commun 2011;32:708-15.

Copyright 2018 BMJ Publishing Group. All rights reserved. For permission to reuse any of this content visit

http://group.bmj.com/group/rights-licensing/permissions.

BMJ Case Report Fellows may re-use this article for personal use and teaching without any further permission.

Become a Fellow of BMJ Case Reports today and you can:

- Submit as many cases as you like

- Enjoy fast sympathetic peer review and rapid publication of accepted articles

- Access all the published articles

- Re-use any of the published material for personal use and teaching without further permission

For information on Institutional Fellowships contact consortiasales@bmjgroup.com

Visit casereports.bmj.com for more articles like this and to become a Fellow 